\title{
Comics as an Alternative Learning Media for Introductory Accounting Course
}

\author{
Vita Fitria Sari ${ }^{1}$
}

${ }^{1}$ Dept. of Accounting, Faculty of Economics, Universitas Negeri Padang, Padang, Indonesia

$\triangle$ (e-mail) vitafitriasari@gmail.com

\begin{abstract}
Introductory Accounting course is the basic course for accounting student which one of the topic is accounting cycle of services company. Accounting of service company can be considered as a foundation in understanding other topics in introductory accounting course. Problems arise since lecturers still use traditional method in teaching such as preaching method which considered less interesting by students. Lecturer should adopt innovative and creative learning media to ensure students' attention. This study aims to propose the use of comics as a learning media to improve students' understanding in accounting cycle of service company on introductory accounting course. This study used an experimentation, which classified as pre-experimental (non-design) by the method of the one group pretest - posttest design. The results indicate that there are differences in students' understanding of accounting cycle of service company before and after the use of comics as learning media. Comics as learning media in introductory accounting course can improve the students' understanding on accounting cycle of service company. Therefore, comics can be recommended as one of the alternative learning media to be used in the classroom. However, it does not mean that comics can replace lecturers' role as an educator. Indeed, comics can be used as a tool to maintain students' attention in class and to improve their understanding in such topic.
\end{abstract}

Keywords: accounting cycle, comics, introductory accounting, learning media, service company

\section{Introduction}

Accounting discipline needs more hours of teaching and learning to improve students' understanding. This course is not enough to be taught in a classroom only. Thus, faculty provides students with two lecture sessions for the subject, theory and practice sessions. Yet it is still not enough; students are required to undertake independent study outside the classroom either individually or in groups. Both classroom teaching and independent study are aimed to increase students' understanding on accounting subject. Furthermore, in proposing to increase students accounting subject, it is necessary to have effective learning media for the students.

The media used in the teaching and learning process has an important role since media as intermediary tools of teaching and learning activities. The hassle of learning materials can be further simplified with the help of the media. Learning media can represent what the less capable lectures tell students through certain words. Furthermore, media helps to explain in terms of abstract materials. Accounting of service company is one of important basic material in accounting that will support students in other accounting material such as accounting of trading and manufacturing company. Accounting cycle of service company contains most of the process or the applicable accounting cycle in trading and manufacturing companies. In other words, a good understanding of accounting service company will support the students' understanding on accounting of trading as well as manufacturing company.

A preliminary observation of teaching and learning process was carried out focusing on the topic of accounting for service company in introductory accounting course. The results show that the students tend to be passive during the teaching and learning process, i.e. only listening to lecturer. The classroom condition shows that most students are busy with their own activities, like chatting, playing phone or still listening to lecture explanation but not focus to study. This condition is often occurred because the 
learning methods are still using a traditional lecture method (i.e. preaching method). Lecture or preaching method is a method of teaching with information and knowledge orally to learners (students). Lecture method, generally lead to students' passivity, it causes students to feel saturated and bored. Preaching method lead students to pay less attention to the material being taught and result in students absorbing just the small proportion of the materials. Therefore, innovation in accounting learning is needed to increase understanding of the introductory accounting material, particularly related to accounting for service company.

In this digital era, many different kinds of media have been developed as learning media. Interesting media is one of strategies that enhance students' understanding. Sudrajat (2008) mentions the different kinds of media, namely, (1) visual media, (2) audio media, (3) projected media, and (4) projected motion media. One form of visual media is comic. Several media have been developed to support learning and make learning becomes fun and interesting. Of course, it is done by taken into account the main purpose of media as a tool of learning to promote students' understanding.

Learning media designed in this study is a comic. Why comics? Comics can be used as a motivational and educational tool for adults and children in variety of teaching and learning settings (Berkowitz \& Packer, 2001). There are three reasons why comics are useful as teaching tools: (1) there is a great deal of student's interest with comics (2) comics are not expensive enough in price; and (3) the vocabulary is not difficult to read (Wright, et al., 1999). Other advantages of comic books is lowcost presenting, accessible, familiar, and highly engaging medium to guide, entertain, and inspire students in many areas (Berkowitz \& Packer, 2001).

Comics have been developed as learning media over years in multidiscipline subjects. Cheesman (2006) has use comics strips in newspaper and magazine as learning media in science classroom to assess both student and teachers understanding of science concepts. He found that comics can increase students' attention in classroom; it can be used to introduce a new topic, and stimulate students' critical thinking and ethical discussion in the classroom. Comics can be used as a tool to communicate some important points that elementary science teacher prepared with narratives material (Arroio, 2011).

There are two ideas about the advantages of using comics in a classroom. First, reading comics involve a complex and multi-literacy. Second, comics can help students to develop their critical thinking and engaged readers to multi-texts (Jacobs, 2007). A comic is made by visual images with words which help students to develop visual literacy. Comics also offer an opportunity for students to scrutinize the interdependent images and word to create a strong sequential narrative (Marie, et al., 2008). Furthermore, comics create opportunities for teachers and engage students in meaningful discussion about visual perception, drawing and design art history, and content on multiple levels (Berkowitz, et al., 2001).

The use of comics as learning media in accounting course is still under study. Mediawati (2011) uses comics as learning media for intermediate accounting to improve students' performance. The limitedness of using comics as learning media in accounting course encourage researchers to design media comics as an alternative learning media.

The comic in this study is an effort to improve students' understanding of the accounting cycle of service company in the introductory accounting courses. Thus, the objective of this study is to provide evidence on differences of students' understanding before and after the use of the comics as learning media. This study also survey participants' responses towards comics as learning media. This is to know: (1) participants' interests in comics, (2) participants' understanding on the material presented in comics, (3) appearances of the comics, and (4) presentations of the comics.

The remainder of this paper is organized as follows. The next section presents the research methods and is followed by results and discussion. The final section concludes the paper by recommending some limitations and suggestions for future research. 


\section{Methods}

This study used an experimental design. Experimental design is a method of research that is used to search for a particular treatment influence against the other in conditions completely (Sugiyono, 2011). Experimental research is more suitable done in the field of education. This is due to two reasons, namely, (1) teaching method used in the research will be compared naturally and in a situation that is not biased and (2) basic research with the aim of lowering the general theoretical principles into applied science which corresponds to the problems faced by schools.

Experimental research in the field of education differentiated into two, inside and outside the laboratory. Most research that use students as the subjects are conducted outside the laboratory. This is because there are some advantages of research outside the laboratory, including (a) the experimental variables can be stronger; (b) more easily in providing treatment; (c) can do the setting that approximates the actual circumstances; and (d) actual experimental results (Sukardi, 2011).

According to Sugiyono (2011), there are some forms of experimental design. Experimental design used in this research is a type of pre-experimental (non-design) by using pretest - posttest group design. On the one pretest - posttest group design will be a pretest prior to treatment (the treatment). The results of treatment can be assessed more accurately because it can be compared with prior treatment. Variable treatment in this study was the use comics as a learning media which contain material accounting cycle of services companies. The design of chart form is presented in Table 1 as follows.

Table 1 Research Design

\begin{tabular}{|c|c|c|}
\hline 01 & $\mathrm{X}$ & 02 \\
\hline Pretest & Treatment & Posttest \\
\hline
\end{tabular}

The steps in this experiment research were as follows:

1. The existence of a significant problem for the research

Existing problems of learning media accounting is still monotonous. Furthermore, preaching method is still used that lead to less attractive in the process of teaching. Therefore, an innovative learning media of accounting is needed to increase the students' understanding on accounting cycle of service company. The comic is proposed to increase understanding due to uniqueness, interesting and easy to understand.

2. The selection of the subject enough to be divided in groups of experiments

The subject in this study is the first-year students majoring in accounting at Universitas Negeri Padang.

3. The development instruments

The instrument used in this research was the learning media of comics containing material accounting cycle of service company.

4. The selection of design research

The research design was the one group pretest - posttest design.

5. Execution of the procedure

The initial procedure in this study is to carry out a lecture method in explaining the material accounting cycle of service company. This procedure lasted for 6 meetings. At the beginning of the seventh meeting, researchers conducted a pretest to measure the students' understanding of accounting cycle of service company. On the seventh meetings, lectures used comics that contains the accounting cycle of service company materials. At the end of the eighth meetings, a posttest was carried out to measure the influence of using comics on students' understanding of the materials.

6. Data analysis

To see the influence of the media treatment of the comics, the data were analyzed with a different test. It was to see if there are differences in understanding the materials before and after the use of comics as learning media. 
The hypothesis presented in this study is:

$\mathrm{H}_{\mathrm{a}}$ : there is a difference on students' understanding on services company accounting cycle before and after the use of comics as the learning media

\section{Results and Discussion}

Participants in this study were first-year accounting students in Faculty of Economics, Universitas Negeri Padang. The study was done on two classes, class A consisted of 26 students and class B consists of 28 students. There was no specific reason in selecting the two classes, both classes taught by different lecturers for Introductory Accounting 1 course. Table 2 below shows an overview of the participants based on class and gender.

Table 2 Description of Participants

\begin{tabular}{ccccccc}
\hline & \multicolumn{6}{c}{ Gender } \\
\cline { 2 - 7 } & Male & $\%$ & Female & $\%$ & & \\
\hline \multirow{2}{*}{ Class A } & 13 & $50 \%$ & 13 & $50,00 \%$ & 26 & $48,15 \%$ \\
\cline { 2 - 7 } Class B & 13 & $46,43 \%$ & 15 & $53,57 \%$ & 28 & $51,85 \%$ \\
\cline { 2 - 7 } & 26 & $48,15 \%$ & 28 & $51,85 \%$ & 54 & $100 \%$ \\
\hline
\end{tabular}

Based on Table 2, it can be concluded that the participants were dominated by females. Descriptive analysis showed that the average students' understanding on the materials was 14.72 at pretest compared to 16 at posttest. It indicates an improvement in students' understanding of the materials after using comics of 1.28. In summary, it can be said that the use of comics can improve the students' understanding of the services company around 1.28.

Table 3 Changes in Participants' Scores After Using Comics

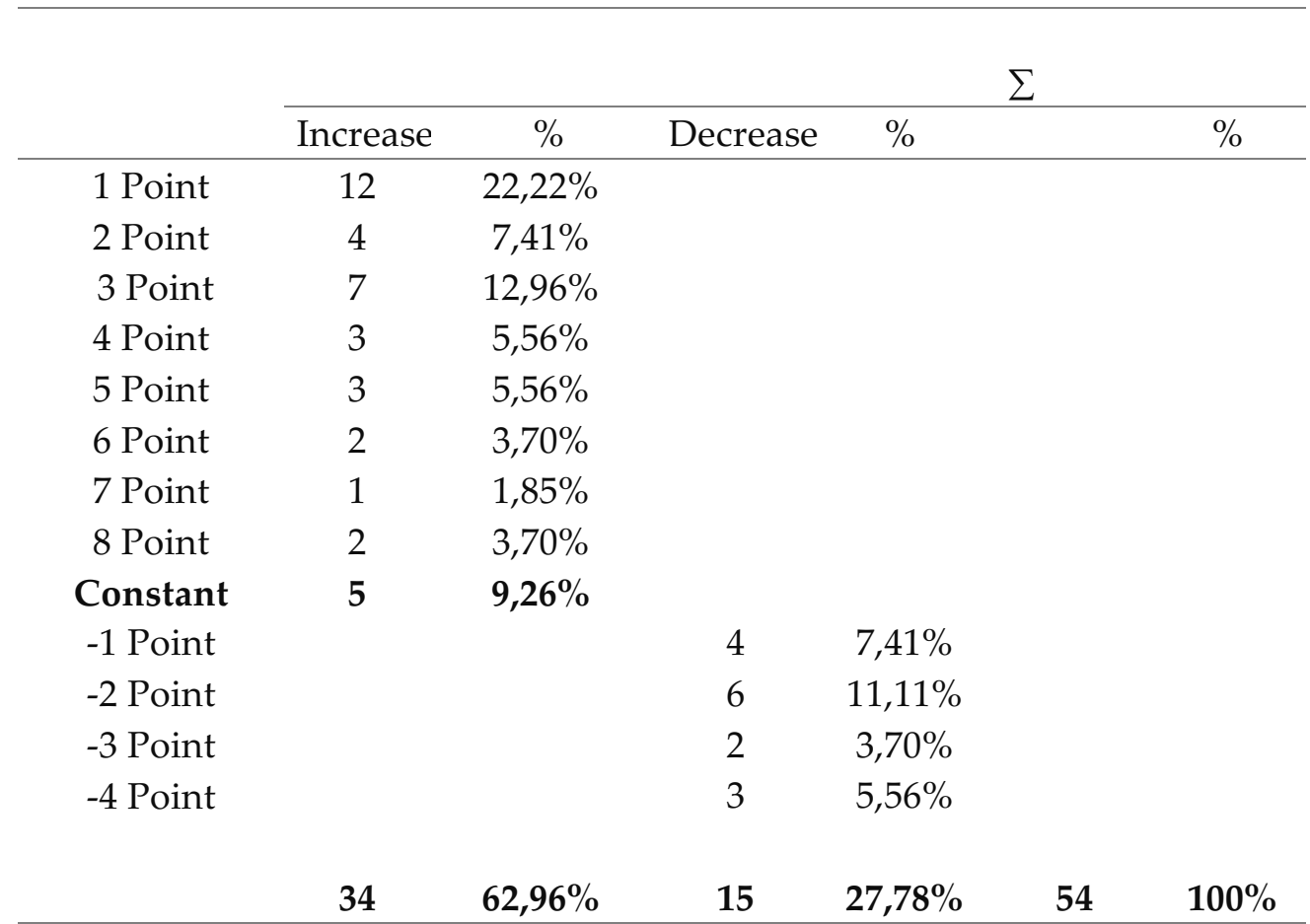

Table 3 below show that $62.96 \%$ of the students experienced improvement in their understanding of the course materials after using comics as learning media. However, $9.26 \%$ get the same score; while $27.78 \%$ participants unfortunately experienced decline in their scores after using comics. Time limitations due the use of comics may cause the decrease. However, this study proves that more than $50 \%$ participants experienced improvement in their scores after using comics as learning media for service company course materials. 
This research aims to see if there is a difference of participants' understanding toward the materials accounting cycle of services company before and after using comics as learning media by using paired samples t-test. Before testing the hypothesis, test of normality was conducted to know whether the data used are distributed normally or not. Testing normality in this research is carried out using one sample Kolmogorov Smirnov test by looking at significant levels of $5 \%$. Based on table test of normality test results show that the data value from pretest data was of 0.161 while for posttest was 0.74 . So, it can be concluded that data in this study is distributed normally. Subsequent hypothesis testing was done by using a paired sample t-tests indicated that the significant value of 0.003 to mean significant value smaller than 0.05 so that the hypothesis in this study is supported. This indicates that there is a difference in understanding to the materials cycle accounting services companies before and after using the comic as a media.

To find out how the opinion of participants about the use of comics as an alternative learning media for Introductory Accounting courses especially for topic accounting cycle of services company, researcher has distributed the research questionnaire consists of four parts questions which are participants interest in comics, do participants understand the material presented in comics, appearance of comics and presentation of comics. To see the validity in each item of the questionnaire questions used corrected item-total correlation. Based on a test of the validity, it can be seen that question is considered valid and reliability more than 0.80 . The use of comics as an alternative learning media for material accounting cycle of Services Company got positive responses from the participants in this study. It can be shown from total response rate which are all more than $75 \%$ for each question.

The results of this research show that there is a difference of understanding participants to the materials cycle accounting services firm before and after using comics as learning. This is in line with (Mediawati, 2011) which found that the results of the study are obtained after student learning using comics in intermediate accounting experience increased compared to the results of students who are not learning to use comics accounting in intermediate accounting. The results also in line with (Cheesman, 2006) which found that comics can increase students' attention in science classroom. It also supported the use of comics in the classroom.

Actually, there are many ways to use comics in classroom but it used mostly to increase students' attention and stimulate critical thinking (Cheesman, 2006). Graphics learning media in the form of comics will provide ease in delivering and receiving material which is considered difficult to be delivered with conventional learning method. The use of comics as a medium of alternative media in learning the material accounting cycle Service Company can minimize the monotonous method used by lecturers and students. By using comics, it will create a new atmosphere that can help students to understand the material of accounting services company cycle. So, it is expected that comics can create effective, attractive, fun, understandable teaching, and to resolve the matter with time limitation. The use of comics as learning media for materials in accounting cycle of service companies also get positive response from the participants in this study. Comics can be a proper learning media to support material accounting cycle of services companies. However, comic is not necessary to replace lecturer position as an educator; comics are not a way to teach science, but only as a selected tool to teach key concepts and to help students participate in the classroom. (Cheesman, 2006).

Comics can be an alternative learning media to attract students' attention and to improve their understanding in such topic. There are several things to consider before using comics in classroom to ensure positive and productive experience learning. The first one is using single-frame comics which promote students reading and comprehending. The second is using a large image as possible; it will help students to see the image and words clearly. The third is cleaning up newspaper image before using, if your comics taken from newspaper. The fourth, comics can be a tool to allow students to take more in studying time. The last one is being sure that your comics used are appropriate to your audience (Cheesman, 2006). 


\section{Conclusions}

Based on the results of research and discussion, it can be concluded that there is a difference of students' understandings against the material accounting cycle of services companies before and after the use of the media of comics. There is an increasing in the understanding of $62.96 \%$ of participants against the material accounting cycle of Service Company after using media comics. Furthermore, the use of comics as an alternative learning media for material accounting cycle of services company get positive responses from the participants in this study. Comics can be used as one of alternative media in teaching accounting especially accounting cycle of Services Company; but it doesn't mean comics can replace lecturer role in classroom. Comics just can be a tool to attracts students' attention and help them to improve their understanding in such topics.

Some limitations in this research are: (a) research is still using simple cases described in comics related to the material accounting cycle of services company; (b) still use manual comics (c) the time limitations in the use of comics as learning media for accounting cycle of services company; so that it has not shown maximum results yet; (d) types of experimentation that was done in this study a new type of pre-experimental (non-design) by the method of the one group pretest - posttest design.

Hence the advice to next researchers is: (a) the next research can design more complex cases described in comics related to the material accounting cycle of services companies; (b) the next research can develop digital comics. Next researchers also are expected to conduct feasibility trials comics as seen from media experts and expert material in the development of comics as learning media in accounting; (c) future research can develop type of research experiments such as true-posttest only to control experimental design, pretest-control group design or other types of research experiments.

\section{References}

Arroio, Agnaldo. (2011). Comics as a narrative in natural science education. Conference on Western Anatolia Journal of Educational Sciences. Turkey: Dokuz Eylul University Institute.

Berkowitz, J., \& Packer, T. (2001). Heroes in the classroom: Comic books in art eduaction. Art Education, 12.

Cheesman, Kerry. (2006). Using comics in the science classroom. Journal of College Science Teaching, 48.

Jacobs, Dale . (2007). More than words: Comics as a means of teaching multiple literacies. English Journal, 19.

Marie, R., \& Williams, C. (2008). Image, text, and story: Comics and graphic novels in the classroom. Art Education, 13.

Mediawati Elis. (2011). Pembelajaran akuntansi keuangan melalui media komik untuk meningkatkan prestasi siswa. Jurnal Penelitian Pendidikan, (April).

Sudrajat Ahkmad. (2016). Retrieved from www.wordpress.com on 1 April 2016.

Sugiyono. (2011). Metode Penelitian Kuantitatif Kualitatif dan RED. Bandung: Alfabeta.

Sukardi. (2011). Metodologi Penelitian Pendidikan Kompetensi dan Praktiknya. Jakarta: PT. Bumi Aksara.

Wright, G., \& Sherman, R. (1999). Let's create a comic strip. Reading Improvement, 66. 